\title{
Complementary Books of Gifted High Schools in Iran: A Content Analytic Study
}

\author{
Afsaneh Kalbasi (Corresponding author) \\ Assistant Professore, Department of Professional Education \\ Farhangian University of Isfahan, Iran \\ Tel.: 98-913-303-4336 E-mail: kalbasiafsaneh@gmail.com
}

\begin{abstract}
Ahmad Reza Nasr Esfahani
Department of Educational Sciences, Faculty of Educational Sciences and Psychology

University of Isfahan, Isfahan, Iran
\end{abstract}

Seyed Ebrahim Mir Shah Jafari

Department of Educational Sciences, Faculty of Educational Sciences and Psychology

University of Isfahan, Isfahan, Iran

\author{
Ahmad Abedi \\ Department of Educational Sciences, Faculty of Psychology \\ University of Isfahan, Isfahan, Iran
}

Received: Nov. 24, 2017 Accepted: Feb. 23, 2018 Published: February 23, 2018

doi:10.5296/jse.v8i1.12185 URL: https://doi.org/10.5296/jse.v8i1.12185

\begin{abstract}
In Iranian educational system, there are special schools offering specialized curriculum for gifted students. In the curriculum of their first degree high school course, complementary contents have been provided in order to improve the process of learning. The objective of the present study has been to evaluate the content of such books which has played a pivotal role
\end{abstract}




\section{Macrothink}

in educational process of Iranian gifted schools. We employed the triangulation method. The project was implemented between September 2014 to September 2015 by interviews and researcher-based questionnaires provided by principals, assistant principals, consultants and teachers of middle schools from gifted schools of the Isfahan province of Iran. The reliability coefficient of the questionnaire was 0.88 based on Cronbach's alpha. In order to analyze the qualitative and quantitative data, categorical analysis and descriptive statistics have been applied, respectively.

Our questionnaire results showed that the four evaluated complimentary books were in quite desirable status. Based on the findings from the interviews and evidences from the gifted education literature we suggest principles by which selection and revision of complementary contents can be possible. Such principles are as follows: (i) content deepening, (ii) integrative and interdisciplinary organization, (iii) to be problem-oriented, (iv) understanding daily life use of the knowledge and (v) classification of exercises based on their complexity level.

Keywords: Gifted education, complimentary books, content analysis, Iran 


\section{Introduction}

Individual differences of intelligence, personality, talent, educational achievement, economic and social status and learning ability among students have always been one of the most important challenges that teachers encounter. It seems that a common curriculum may not be advantageous for all the students. Rational and specialized design is crucial to empower gifted students' unique features. An appropriate curriculum for gifted students should be based on individual differences and special needs of this group.

Gallagher (1985) has identified four major ways in which curricula content has been modified to meet the special needs of gifted students. These categories are acceleration, enrichment, sophistication, and novelty. Content acceleration refers to the presentation, to gifted students, of curricula that was intended for older students. Content enrichment refers to the variety of extra lessons or assignments used to elaborate the richness of understanding the student has of the existing curriculum goals. Content sophistication refers to attempts to challenge gifted students to learn the more complex and sophisticated information from the curriculum that the average student might not be able to master. Content novelty refers to curriculum efforts that present content that is not covered in traditional school curriculum(Gallagher, 1994).

Schiever et al (2003) pointed out various instruction experiences and deeper contents in defining a modified curriculum for gifted students. These modifications might be content oriented, process oriented or product oriented. As one of the elements of curriculum, the content includes facts, concepts and skills which is supposed to be learned in every level. In content oriented modificational approach, the content of the lessons such as mathematics, science, literature and social sciences are rendered with more depth and complexity; in other words, in content differentiation, emphasis is placed more on the principles, concepts and basic methods of every discipline. Moreover, museum and science centers visits make the curriculum more effective.

In the process-oriented approach, the emphasis is on high-level mental processes in Bloom's cognitive domain, creative problem solving, creative production and problem finding skills and problem solving and also inquiry based learning. The point which is worth mentioning is that the students are expected to comprehend internal relationships between the concepts and lessons; however, it will not be possible unless instructing thinking skills about situations they would face in real life. In the product oriented approach, objective and tangible results such as presenting a report, drawing, versing, or presentation of an article in a meeting are emphasized. Differentiating between product or the result gives the students opportunity to show their ability and creativity (Levy, 2008).

Van Tassel-Baska and Stambaugh (2009), also, emphasized on three dimensions of curriculum composing of content, process and products in designing appropriate curriculum for the gifted students at different developmental stages and various learning areas. They considered the content mastery, high-level process, product development, and studying overarching concepts and themes as pivotal elements in an appropriate curriculum. 
Beecher and Sweeny (2008) in line with presenting a model, summed up different types of differentiation of curriculum in the content, process and product. Their instruction strategies in differentiation included creative problem solving, curriculum compacting, tiered activities, problem solving based learning and inquiry based instruction.

Creative problem solving is composed of five stages: Mess finding, Problem Finding, Data finding, Solution finding and acceptance finding (Treffinger \& Isaksen, 2005).

In the curriculum, compacting occurs when some opportunities are provided for educational challenges in the fields of interest by omitting the contents which students have overcome (Winebrenner, 2003).

Tiered activities are learning activities which are performed based on emphasis on the standards, skills and basic concepts as regards the appropriate ability of each gifted student. All the students should concentrate on content, but each with different depth and complexity. (Sondergeld \& Schultz, 2008).

Gifted students enjoy posing real life questions. Inquiry based instruction and problem-oriented learning would be an excellent opportunity to challenge such students. Planning an open-ended exploratory content to learn can result in success of all the students specially gifted ones. In the inquiry based instruction students are seeking the solution for the real life issues and reporting the study results (Van Tesel Baska and Brown, 2005). For example, a well-designed, inquiry based biology curriculum owns variable, flexible and challenging presentation pace and provides the possibility of a functional feedback through common evaluations.

The research results regarding the features of desirable content show that the integrated organization is one of the most important points in compiling appropriate contents to instruct gifted students. Estes (2007) believed that through integrated curriculum between biology and other science, mathematics, technology, art and liberal arts; an ideal learning environment is provided.

Furthermore, in Sriraman \& Dahl's view (2009), integrated organization of the content can provide more learning opportunities for gifted students in order to find out the relationship between this science and its applications in daily life besides learning a science such as mathematics.

On the other hand, the chemistry subject provides many opportunities for learning processes of gifted students. Spiral curriculum, interdisciplinary learning and knowledge complexity, are important structures of chemistry curriculum. Because of this, enrichment programs compile most of their content based on this subject. Further, the structural nature of chemistry, makes individual activities and independent learning possible. Studies show that the most important characteristic of learning in chemistry is interdisciplinary integration and variety in knowledge types (Kerr, 2009).

In Iranian educational system, there are special schools offering specialized curriculum for gifted students. In the curriculum of their first degree high school course, complementary 
contents have been provided in order to improve the process of learning. In instructing exceptionally talented students in our country, Iran, there have been complimentary text books to enrich lessons' content for more than two decades. As far as we are aware, up until now, there have boon no study evaluating the content of such complementary books in our country. This study, for the first time, was planned to evaluate complementary books of gifted high schools of Iran by content analysis. The objective of the present study has been to evaluate the content of such books which has played a pivotal role in educational process of Iranian gifted schools. We employed the triangulation method by interviews and researcher-based questionnaires provided by principals, assistant principals, consultants and teachers of middle schools from gifted schools of the Isfahan province of Iran.

\section{Materials and Methods}

This was a descriptive survey using mixed qualitative and quantitative methods. The most common approach in mixed methods is the triangulation design. The objective of the triangulation design is to achieve different but complementary data about a specific subject and to better understand research question; in other words, by such design we meant to avoid drawbacks of each method by the other one's advantageous points (Creswell \& Plano Clark,2007, P64).

To evaluate the content of complimentary books of first degree high school gifted students -- including chemistry, biology, physics and mathematics books -- interview and researcher-made questionnaire were used. Interview instrument included the following one question: "What features should the content of complementary books of gifted students' should have?"

The researcher-made content-evaluation questionnaire was compiled via research literature in instructing the gifted, analysis method of lesson books by Fathi (2007), and content analysis method of critical thinking by Garrison, et al (2001). The questionnaire was designed according to five areas of content nature, the gifted nurturing approaches, learning activities, principles of designing and organizing content and images of complimentary books. The validity of the questionnaire was examined by four experts in curriculum planning, who were the authors of the present report (A. K.; A. N.; A. A.; and, S-E. M.) and 4 teachers of the evaluated book subjects. Reliability was determined 0.88 via Cronbach alpha coefficient and deleting ambiguous points.

\section{The sample and sampling method}

The target population of this study was all the managing staff at gifted first degree high schools in the Isfahan province of Iran including 8 principals, 16 assistant principals and 8 consultants. In order to administer the above mentioned questionnaire, 24 individuals in four groups of six employed teachers at the same schools were selected through purposive sampling method. They were grouped based on the teaching subjects of chemistry, biology, mathematics and physics.

Data analysis method: To analyze the interview data the categorization method with the following stages was used: providing the data, organizing the data, reduction and 
summarizing the data in the form of categories through coding and combining codes and finally present the findings in the form of tables. According to it, after some investigation of implemented data and meticulous examination of descriptive answers of the participants, some categories were diagnosed and selected.

The questionnaire was regulated based on the five-grade Likert scale from 'very much' to 'very little'; the numerical values of each scale included: very much $=5$; much $=4$; medium=3; little $=2$; and, very little $=1$. If the continuum of 1 to 5 is divided into three equal parts, 1-2.33, 2.34-3.66 and 3.67-5 are assumed 'undesirable', 'quite desirable' and 'desirable', respectively.

\section{Study findings}

Analysis results of the interviews on the features of desirable complimentary contents are summerized in table 1. Results of analyzing the teachers' views about complimentary books via questionnaires have given in table 2 .

Table 1. Main categories related to desirable content of complimentary books

\begin{tabular}{|c|c|}
\hline Main categories & Features of desirable complimentary content \\
\hline The criteria of content selection & new, applicative and validated \\
\hline $\begin{array}{c}\text { Agreement of content to the objectives of } \\
\text { instructing the gifted }\end{array}$ & $\begin{array}{c}\text { Nurturing creativity, exploration spirit and problem solving } \\
\text { skill, more emphasis on content enrichment and its necessary } \\
\text { deepening, Attention to the effect of content in inspiring } \\
\text { positive attitudes and moral values. }\end{array}$ \\
\hline $\begin{array}{c}\text { The manner of content organization } \\
\text { Agreement of the content to the } \\
\text { individual differences and the students' } \\
\text { interests }\end{array}$ & $\begin{array}{c}\text { Interdisciplinary integration and organization of different } \\
\text { lesson contents, Observing horizontal and vertical } \\
\text { organization in compiling the content, Attention to the } \\
\text { coordination of instruction hours and lesson content. }\end{array}$ \\
\hline $\begin{array}{c}\text { Attractive and motivating content presentation, Attention to } \\
\text { differences, Attention to the kinds of learning styles, } \\
\text { Attention to optional lessons to motivate the students' } \\
\text { interests }\end{array}$ \\
\hline $\begin{array}{c}\text { The application of technology in content } \\
\text { presentation }\end{array}$ & \begin{tabular}{c} 
Content presentation in electronic and multimedia formats \\
\hline
\end{tabular}
\end{tabular}

In table 2, total means range from 2.34 to 3.66, which can be classified as 'quite desirable'. In table 2, as regards the 'classification of exercises based on their complexity level'; chemistry, physics and biology books have had the lowest mean. 


\section{Ml Macrothink}

Journal of Studies in Education

ISSN 2162-6952

2018, Vol. 8, No. 1

Table 2. Content analysis results of complimentary books of chemistry, physics, biology, and mathematics in the first year of high school

\begin{tabular}{|c|c|c|c|c|c|}
\hline \multirow{2}{*}{ Areas } & \multirow{2}{*}{ Items } & \multicolumn{4}{|c|}{ Mean } \\
\hline & & chemistry & physics & biology & Mathematics \\
\hline \multirow{4}{*}{$\begin{array}{l}\text { Content } \\
\text { nature }\end{array}$} & $\begin{array}{l}\text { 1- Clear definition of major and minor } \\
\text { purposes }\end{array}$ & 3.16 & 3.6 & 3.3 & 3.6 \\
\hline & $\begin{array}{l}\text { 2- agreement of content difficulty level with } \\
\text { the learners' experiences }\end{array}$ & 3 & 3.5 & 3.8 & 3.2 \\
\hline & $\begin{array}{l}\text { 3- Considering a rational simple-to-complex } \\
\text { ordering }\end{array}$ & 3.16 & 3.3 & 4 & 3.8 \\
\hline & 4. Newness of the content & 2.8 & 2.5 & 3.16 & 3.8 \\
\hline \multirow{12}{*}{$\begin{array}{c}\text { Approaches } \\
\text { of } \\
\text { nurturing } \\
\text { the gifted }\end{array}$} & $\begin{array}{l}\text { 5. Inspiring positive attitudes and moral } \\
\text { values }\end{array}$ & 3 & 3.5 & 2.8 & 3.2 \\
\hline & $\begin{array}{l}\text { 6. Motivating the learner through posing } \\
\text { questions }\end{array}$ & 2.6 & 3.5 & 3.3 & 3.4 \\
\hline & $\begin{array}{l}\text { 7. Encouraging the learner to critical } \\
\text { thinking }\end{array}$ & 2.5 & 3.3 & 3 & 3.4 \\
\hline & $\begin{array}{l}\text { 8. Making questions with answers not } \\
\text { directly answered in the text }\end{array}$ & 3.3 & 4 & 3.3 & 3.8 \\
\hline & $\begin{array}{l}\text { 9. Getting the learner to know research and } \\
\text { its stages }\end{array}$ & 2.8 & 4 & 3 & 3.2 \\
\hline & $\begin{array}{l}\text { 10. Reinforcing exploaration skills } \\
\text { (observation, comparison, measurement and } \\
\text { information analysis) }\end{array}$ & 2.8 & 3.6 & 3.5 & 3.2 \\
\hline & $\begin{array}{l}\text { 11. providing real life application of the } \\
\text { science }\end{array}$ & 3.1 & 3.6 & 2.8 & 3.2 \\
\hline & $\begin{array}{l}\text { 12. Providing activities and learning } \\
\text { experiences and various experiments to } \\
\text { deepen learning }\end{array}$ & 3.5 & 3.6 & 2.6 & 3 \\
\hline & $\begin{array}{l}\text { 13. Providing learning experiences through } \\
\text { predicted experiments in the book } \\
\text { independent from the teacher's role }\end{array}$ & 3.5 & 3.3 & 2.8 & 3 \\
\hline & $\begin{array}{l}\text { 14. Agreement of the content with the } \\
\text { features such as learners' natural/social } \\
\text { environment }\end{array}$ & 3 & 3.1 & 3.3 & 2.6 \\
\hline & $\begin{array}{l}\text { 15- investigating the relationship between } \\
\text { lessons and other sciences }\end{array}$ & 2.5 & 2.5 & 3.16 & 2.4 \\
\hline & 16- Supporting independence in learning & 3.16 & 3.1 & 3 & 3 \\
\hline \multirow{2}{*}{$\begin{array}{l}\text { Learning } \\
\text { activities }\end{array}$} & $\begin{array}{l}\text { 17- Agreement of learning activities to the } \\
\text { content }\end{array}$ & 4 & 3 & 3.5 & 3.4 \\
\hline & $\begin{array}{l}\text { 18- Variability of the exercises and learning } \\
\text { activities (problem solving, observation, }\end{array}$ & 3.5 & 3.3 & 3.1 & 3.4 \\
\hline
\end{tabular}




\begin{tabular}{|c|c|c|c|c|c|}
\hline & $\begin{array}{l}\text { explanation, comparison, drawing graph, } \\
\text { commenting) }\end{array}$ & & & & \\
\hline & $\begin{array}{l}\text { 19- Reinforcing different skills of } \\
\text { exploration, innovation and generalization }\end{array}$ & 3 & 3 & 3 & 3.2 \\
\hline & $\begin{array}{l}\text { 20- classification of exercises based on their } \\
\text { complexity level }\end{array}$ & 2.3 & 2.3 & 2.3 & 3 \\
\hline \multirow{7}{*}{$\begin{array}{l}\text { Design } \\
\text { principles } \\
\text { and content } \\
\text { organizing }\end{array}$} & 21- Rational organization & 3.6 & 3.1 & 3.16 & 3.2 \\
\hline & $\begin{array}{l}\text { 22- Agreement of chapters length to their } \\
\text { subjective importance }\end{array}$ & 3.6 & 2.6 & 3.6 & 3.6 \\
\hline & $\begin{array}{l}\text { 23- Observing the principles of content } \\
\text { design (font size, using blank space, font } \\
\text { type) }\end{array}$ & 3.5 & 3.5 & 4 & 3.4 \\
\hline & $\begin{array}{l}\text { 24- Harmony of the applied language with } \\
\text { the learners' age }\end{array}$ & 3.5 & 3 & 4 & 3.6 \\
\hline & $\begin{array}{l}\text { 25- Leaners' comprehention (agreement of } \\
\text { sentences length) }\end{array}$ & 3.5 & 3.1 & 3.6 & 3.2 \\
\hline & $\begin{array}{l}26 \text { - Suggestion of resources for further } \\
\text { study }\end{array}$ & 3 & 2.3 & 3 & 2.6 \\
\hline & $\begin{array}{l}\text { 27- Graphical/ tree diagram presentation of } \\
\text { the material }\end{array}$ & 2.8 & 3.6 & 2.8 & 3.2 \\
\hline \multirow{5}{*}{ Images } & 28- Harmony of images with the text & 3.3 & 3.6 & 3.8 & 3.7 \\
\hline & $\begin{array}{l}\text { 29- The abiliy of information transferring to } \\
\text { the learner }\end{array}$ & 3.16 & 3.5 & 3.6 & 3.4 \\
\hline & 30- Attractiveness and effective coloring & 3.5 & 3.8 & 4 & 3.4 \\
\hline & 31- Balanced distribution & 3.3 & 3.16 & 3.5 & 3.2 \\
\hline & $\begin{array}{l}\text { 32- Presentation of comprehensible } \\
\text { explanations }\end{array}$ & 3.3 & 3.3 & 3.6 & 3.7 \\
\hline
\end{tabular}

In complimentary books of chemistry and biology, lack of graphical/ tree diagram presentation of the material is considered a disadvantage.

As the results show, disadvantages of complimentary books of chemistry and physics include not being updated and insufficient richness, lack of 'classification of exercises based on their complexity level' and not addressing the relationship between assumed lesson and other lesson are of high importance.

Regarding the complimentary book of biology lack of providing real life application of the science, lack of providing learning experiences, and predicted experiments and lack of offering headlines of contents graphically or by tree diagram are among the disadvantages.

In the complimentary book of mathematics lack of addressing the relationship between lesson and other sciences, lack of making motivation for the learners and also lack of agreement of 
content with some features like the learners' natural environment and social environment are among the disadvantages.

\section{Discussion and conclusion}

One of the reputed principles in education, is the attention to individual differences and learners' individual needs to harmonize instruction with one's ability. Since the value of a curriculum depends on its components, the objective of the present study was to evaluate complimentary content of the curriculum of the exceptionally talented first high schools. The interview results of the present study were in line with the findings of Estes (2007), Sriraman and Dall (2008) and Kerr (2009), by which integrative organization was emphasized. Moreover, we found that in these books, (a) the manner of organizing the material in the form of crude knowledge, (b) instructing contents of senior levels to junior students and, (c) insufficient attention to thinking, creativity and problem solving are among the flaws of these books. On the other hand, these books do not offer optional lessons to students of first high school ages; based on the importance of selection ability and individual independence, such an approach can cause disappointment. The other drawback is frequent simplistic presentation of subjects without necessary deepening of the content by necessary real-life examples and experiments/workshop activities. Furthermore, the findings of table 2 on content analysis results of complimentary books indicated that the mathematic book lacked agreement between content with learners' natural environment. This is in contrast with the recommendations of Sriraman and Dall (2009), Estes (2007), and Kerr (2009) about the need for relationship between lessons and their real life applications.

Taking together, we recommend that the following principles should be considered in content preparation:

1. Integrative/interdisciplinary organization in compiling content.

2. Problem orientation in selecting and compiling contents and proposing real-life application.

3. Acknowledging being research oriented and having exploration spirit by planning challenging and attractive activities.

4. Flexibility in selection and presentation of the content and encouraging teachers to employ technology in providing electronic and multimedia contents.

5. Offering various optional lessons based on their interests.

6. classification of exercises based on each lesson's complexity level

\section{References}

Beecher, M., \& Sweeny, S. M. (2008). Closing the achievement gap with curriculum enrichment and differentiation: One school's story. Journal of Advanced Academics, 19, 502-530. https://doi.org/10.4219/jaa-2008-815 
Creswell, J. W., \& Plano Clark, V. L. (2007). Designing and conducting mixed methods research. Thousand Oaks, CA: Sage.

Estes, F. (2007). Inquiry sciences for young gifted students: The pleasure of finding things out. Gifted Education Communicator, 38(4).

Fathi Vajargah, K, \& Aghazadeh, M. (2007). A guide to designing a textbook. Aiezh Publication, Tehran, Iran. 172-182.

Gallagher, J.J. (1994). Current and historical thinking on education for gifted and talented students. https://eric.ed.gov/?id=ED372584

Garrison, D. R., Anderson, T., \& Archer, W. (2001). Critical thinking, cognitive presence, and computer conferencing in distance education. American Journal of Distance Education, 15(1), 7-23. https://doi.org/10.1080/08923640109527071

Kerr, B. (Eds.). (2009). Encyclopedia of giftedness, Creativity and talent. Sage publications, Inc. https://doi.org/10.4135/9781412971959

Levy, H. M. (2008). Meeting the needs of students through differentiated instruction: Helping every child reach and exceed standards. The Clearing House, 81(4), 161-165. https://doi.org/10.3200/TCHS.81.4.161-164

Schiever, S. W., \& Maker, C. J. (2003). Enrichment and Acceleration: An overview and New Directions. In N. Colangelo \& G. A. Davis (Eds.), Handbook of gifted education. Boston: Allyn \& Bacon. 113-125.

Sondergeld, T. A., \& Schultz, R. A. (2008). Science, standards, and differentiation: It really can be fun! Gifted Child Today, 31(1), 34-40. https://doi.org/10.4219/gct-2008-694

Sriraman, B., \& Dahl, B. (2009). On bringing interdisciplinary ideas to gifted education. In L.V. Shavinina (Ed.), the international handbooks of giftedness. London: Springer, 1235-1250. https://doi.org/10.1007/978-1-4020-6162-2_64

Tomlinson, C. A. (1999). The differentiated classroom: Responding to the needs of all Learners. Alexandria: VA: Association for Supervision and Curriculum Development.

Treffinger, D. J., \& Isaken, S. G. (2005). Creative problem solving: The history, development and implications for gifted education and talent development. Gifted Child Quarterly, 49(4), 342-353. https://doi.org/10.1177/001698620504900407

Van Tassel-Baska, J., \& Brown, E. F. (2005). An analysis of gifted education Curricular models. In F. A. Karnes \& S. M. Bean (2nd ed.), Methods and Materials for teaching the gifted (pp. 75-106). Waco, TX: Prufrock Press.

VanTassel-Baska, J., \& Stambaugh, T. (2009). Curriculum and Instructional Considerations in Programs for the Gifted. In S. I. Pfeiffer (Eds,). Handbook of Giftedness in Children: Psychoeducational Theory, Research, and Best Practices. Springer. 347-365.

Winebrenner, S. (2003). Teaching strategies for twice-exceptional students. Intervention In School and Clinic, 38(3), 131-133. https://doi.org/10.1177/10534512030380030101 